ISSN:2528-9527

E-ISSN : 2528-9535

YIl Year: 7

Cilt Volume:7

Sayı Issue : 12

Uluslararası Toplum Araştırmaları Dergisi

International Journal of Society Researches

Haziran June 2017

Makalenin Geliş Tarihi Received Date: 08/06/2017

Makalenin Kabul Tarihi Accepted Date: 22/06/2017

\title{
Birinci Dönem Türkiye Büyük Millet Meclisinde Antalya Milletvekilleri (Biyografi Ve Faaliyetleri) $^{1}$
}

\author{
$\underline{\text { Nedim Sarıgüzel }^{*}}$ \\ * Uzman. Selçuk Üniversitesi, Atatürk İlkeleri ve İnkılap Tarihi Bölümü, Konya/Türkiye \\ E-Posta: nsarigüzel@selcuk.edu.trＯRCID: 0000-0002-9099-7005
}

Öz

Birinci Dünya Savaşı sonunda İtilaf Devletleri, Osmanlı Devleti ile yaptıkları Mondros Mütarekesine dayanarak Anadolu'nun büyük bir bölümünü işgal etmişlerdi. İstanbul Hükümeti'nin bu işgallere karşı koyacak gücünün olmadı̆̆ını gören Mustafa Kemal Paşa, Anadolu'ya ayak basığı ilk andan itibaren gücünü milletten alan bir mücadele anlayışı belirlemiştir. Anadolu'da yapılan çalışmalar sonucunda Milli Mücadele'ye yön verecek ve Türk Milleti adına karar alacak bir meclis kurulması kararlaştırılmıştır. Antalya milletvekilleri, gerek Birinci Meclis'te, gerekse İkinci Meclis'te tüm yeteneklerini ortaya koyarak çalışmışlar, Milli Mücadele'nin kazanılmasında ve Türkiye Cumhuriyeti'nin kurulmasında önemli hizmetlerde bulunmuşlardır. Antalyalılar, vatanın düşman işgali altında olduğu dönemde Müdafaa-i Hukuk Cemiyeti'ni kurarak ve TBMM'ne gönderdikleri milletvekilleriyle Milli Mücadele'ye destek olmuşlar, Yurdun düşman işgalinden kurtulmasında ve yeni Türk Devleti'nin kurulmasında önemli katkıda bulunmuşlardır.

Anahtar Kelimeler: 1. Dünya Savaşı, Antalya, TBMM.

\footnotetext{
${ }^{1}$ Uzman Nedim Sarıgüzel'in Birinci ve Ikinci Dönem Türkiye Büyük Millet Meclisinde Antalya Milletvekilleri (Biyografi ve Faaliyetleri) isimli yüksek lisans tez çalışmasından üretilmiştir.
} 
ISSN:2528-9527

E-ISSN : 2528-9535

YIl Year: 7

Cilt Volume:7

Sayı Issue : 12

Uluslararası Toplum Araştırmaları Dergisi International Journal of Society Researches

Haziran June 2017

Makalenin Geliş Tarihi Received Date: 08/06/2017

Makalenin Kabul Tarihi Accepted Date: 22/06/2017

\title{
Member Of Parliament During First Era In Grand National Assembly Of Turkey (Biographies And Activities)
}

\begin{abstract}
The Allies occupied the whole Anatolia after the World War the 1st by excusing the treaties which they got signed under compulsion. Mustafa Kemal Atatürk who noticed that İstanbul Government could not resist to these occupancies determined a National Struggle approach which has its power from the nation itself from the time he stepped to Anatolia. An assembly which will give way to National Struggle and will make decisions instead of Turkish Nation was decided to be founded after practices made in Anatolia. Member of Parliament of Antalya worked hard either in the 1st Parliament or in the 2 nd Parliament by showing much effort and they gave important service in formation of Turkish Republic and Gaining National Struggle. Antalya people supported National Struggle by founding Müdafaa-i Hukuk Society in the occupancy period with their members of parliament. They had important contributions in formation new Turkish State and saving the homeland.
\end{abstract}

Key Words: World War The First, Antalya, TBMM.. 


\section{Giriş}

Avrupalılar, Osmanlı Devleti'nin iç işleriyle her zaman yakından ilgilenmişlerdir. Bu ilgilerinin en büyük nedenlerinden birisi Osmanlı İmparatorluğu'nda yaşayan Hıristiyan topluluklardır. İlk kez 1815'te Viyana Kongresi'nde kullanılan "Şark Meselesi" kavramı Osmanlı topraklarında yaşayan Hristiyanların durumuna dikkatleri çekmek için ortaya atılmıştır. Şark meselesi, XIX. yüzyılın ilk yarısında Osmanlı İmparatorluğu'nun toprak bütünlügünün korunması anlamında kullanılırken XX. yüzyıla gelindiğinde Osmanlı topraklarının tamamen paylaşılması anlamında kullanılmıştır (Karal, 1983, s. 203-204).

Birinci Dünya Savaşından sonra oluşan durum Türk topraklarının tamamen parçalanarak Şark Meselesinin temelden çözümlenmesine zemin hazırlamıştır. İtilaf Devletleri Mondros Mütarekesine dayanarak Anadolu topraklarını işgale başlamışlardır. Anadolu topraklarında yaşanan bu haksız işgale karşı Türk milleti tepki göstermiştir. İtilaf Devletleri, başlarda bu tepkileri ciddiye almasada 28 Ocak 1920'de Misak-1 Milli'nin İstanbul'da toplanan Osmanlı Mebusan Meclisin' de kabul edilmesi ve millî hareketin gün geçtikçe taraftarlarının çoğalması üzerine harekete geçen İngilizler, 16 Mart'ta İstanbul'u işgal etmişlerdir.

Osmanlı Mebusan Meclisi de 18 Mart 1920'deki son toplantısınin ardından süresiz tatil edilmiş ve 11 Nisan'da da padişah tarafından feshedilmiştir (Tosun, 1994, s. 18-20).

İstanbul'un işgal edilmesiyle Meclis-i Mebusan'ın kapatılması üzerine Mustafa Kemal Paşa, olağanüstü yetkilere sahip bir Meclisin Ankara'da yeniden toplanması için Heyet-i Temsiliye adına 19 Mart 1920 tarihinde bir beyanname yayınlamıştır.

Gerekli hazırlıklar tamamlandıktan sonra Türkiye Büyük Millet Meclisi 23 Nisan 1920 tarihinde açılmıştır. 26 Nisan 1920 tarihinde de Meclis Başkanlık Divanı oluşturularak Meclis Başkanlığına Mustafa Kemal Paşa getirilmiştir (Aksoy, 2006, s. 232).

Meclisin açılmasıyla birlikte Türk milletinin istikbali bu kutsal yap içerisinde şekillendirilmiş, Millî Mücadele'nin önemli kararları burada alınmıştır. Dünya tarihinde eşine rastlanamayacak kadar büyük bir mücadele gösteren Türk milleti her türlü sefalete ve imkânsızlıklara rağmen Millî 
Mücadele'de destan yazarak Türk'ün bağımsızlı̆ından taviz vermeyeceğini göstermiştir.

\section{Antalya'da Milli Mücadele}

Birinci Dünya Savaşı başladığında İtalya'nın, Anadolu üzerinde ekonomik ve siyasi etkisi İngiltere, Fransa ve Almanya gibi o coğrafyaya hâkim devletlere göre çok zayıftı. İtalya, diğer emperyalist devletlerin de istediği gibi yeni sömürgeler elde etmek istiyordu. Antalya bölgesi, yakın doğuda sömürgeci bir siyaseti yerleştirmek için hâla yaşam alanı bulunan tek bölge olarak görünüyordu. İtalya'nın, sermayesinin kendisi için uygun olduğunu düşündüğü her toprak parçası İngilizler ve Fransızların da iştahını kabartıyor ve bir şekilde İtalya'nın önü kesiliyordu. İtalya, Libya'daki egemenliğini sağlamlaştırmak ve Osmanlı topraklarından daha fazla pay elde edebilmek için İtilaf Devletleri'nin yanında savaştan galip ayrılması gerektiğinin farkındaydı ve bu birlikteliği büyük bir fırsat gibi görüyordu (Fabio, 2003, s.19-20).

Savaştan sonra yapılan anlaşmalara dayanarak kendisine vaat edilen yerleri işgal etmek için İtalya harekete geçti. Savaş sonrası yapılan anlaşmadan, İtalyanların, Antalya'yı işgaline kadar geçen sürede hiçbir asayiş sorunu yaşanmamıştır. Bu nedenle İtalyanlar, işgal için gerekçeler hazırlamaya çalışmışlardır. İzmir ve İstanbul'a giden posta arabasının soyulması, şehir merkezinde bomba patlaması gibi kendi tertip ettikleri asayişsizlik olaylarını bahane ederek Antalya'yı işgal gerekçelerini belgeliyorlardı. 28 Mart 1919 tarihinde İtalyan Donanması Kavalyere Aleksandro Çano kumandasında Antalya'yı işgal ettiler (Erten, 1996, s.6-7).

İşgal kuvvetlerine karşı memleketin pek çok yerinde olduğu gibi Antalya'da da bazı çalışmalar başlamıştı. İtalya'daki istikrarsızlık da Antalya'da Kuva-yı Milliye' nin çalışmalarını kolaylaştırıyordu. Müftü Yusuf Talat Efendi'nin başkanlığında 21 Haziran 1919 tarihinde Nazilli'deki Heyet-i Merkeziye'ye bağlı olarak çalışacak olan Antalya Müdafaa-i Hukuk Cemiyeti kuruldu.

Cemiyet, Antalya'da Millî Mücadele'ye destek olmak için hizmetlerini sürdürürken Ankara'da bir Meclis açılması kararlaştırılmıştı. Açılacak olan Meclise katılmak için Antalya'da yapılan seçimler sonucunda encümen azasından Rasih (Kaplan), İbrişimzade Mustafa, Antalya Darülhilâfe müderrislerinden Halil İbrahim, Belediye Başkâtibi Hasan 
Tahsin, Korkuteli sabık kaymakamı Ali Vefa Bey'ler seçilmişler ve $29 \mathrm{Ni}$ san perşembe günü Meclise katılmak için yola çıkmışlardır (Erten, 1996, s.6-7). Ayrıca, İstanbul'da İngilizlerin elinden kaçmayı başaran Hamdullah Suphi Bey de Antalya mebusu olarak Meclis'e katılır (Çimrin, 2005, s. 66). Böylece Antalya halkı da Mustafa Kemal önderliğinde kurulan yeni hükümete tüm benliğiyle katılarak esir bir millet olmaktan kurtulma yolunda oluşan Millî Mücadele'ye dâhil olmuştur.

\section{Birinci Dönem Türkiye Büyük Millet Meclisinde Antalya Mil- letvekilleri}

\section{I. Ali Vefa (SEYHANLI)}

\section{I. I. Ali Vefa (SEYHANLI) Bey'in Biyografisi}

Ali Vefa Bey, 1872'de (1288) Kıbrıs- Magosa'da doğdu. Kıbrıslı dava vekili Muhammed Naim Efendi'nin ve Meliha Hanım'ın oğludur (TBMM Arşivi, Tercüme-i Hal Kâğıdı, Şahsi Dosya No: 24, Ek: 1). İlk ve orta öğrenimini Lefkoşa Rüştiyesi'nde tamamladıktan sonra İstanbul'a gelerek Mülkiye Mektebi İdadisi'ne girdi. 1897 Ağustosunda Mektebi İdadisi'nin yüksek kısmından mezun oldu (Çoker, 1980, s. 105).

15 Eylül 1897 tarihinde Suriye vilayeti maiyet memuru olarak memuriyet hayatına başladı. 17 Eylül 1900 tarihinde kaymakamlığa atanma hakkını elde etmiş oldu. Stajını tamamladıktan sonra sırasıyla; 26 Mayıs 1901'de Suşehri kazası kaymakamlığına, 4 Haziran 1906'da Mecitözü Kazası Kaymakamlığı' na atandı. 20 Aralık 1908'de istifa edene kadar Mecitözü Kaymakamlığ1 görevini sürdürdü. 4 Ocak 1910 tarihinde Maan Kaymakamlığı'na atanarak memuriyet hayatına geri döndü. 25 Nisan 1911 tarihinde Salt Kazası Kaymakamlığı'na atandı. 18 Ocak 1913 tarihinde tekrar Maan Kaymakamlığı'na atandı. 9 Haziran 1913 tarihinde azledildi ve yaklaşık bir yıl memuriyet hayatından uzak kaldı. Meclisteki görevine kadar ise sirasıyla; 13 Haziran 1914'den 1 Eylül 1914'e kadar Menemen Kaymakamlı̆̆ı, 26 Ekim 1914'den 19 Temmuz 1915'e kadar Finike Kaymakamlığı ve 23 Temmuz 1915'den 15 Nisan 1919'a kadar Korkuteli Kaymakamlığ1 görevlerinde bulundu (E.S.G.M.A., Memuriyet Hizmet Cetveli, Ali Vefa SEYHANLI, Şahsi Dosya). 
TBMM'nin 1. dönemi için yapılan seçimde Antalya milletvekili oldu. Antalya Müdafaa-i Hukuk Cemiyeti Reisi Müftü Yusuf Talat Efendi'nin tanınan bir kişi olması seçimlerden sonra gizlice Ankara'ya ulaşmasını zorlaştıracağ 1 için seçime katılmaması üzerine Ali Vefa Bey, seçime katıldı (Çimrin, 2005, s.66). 19 Nisan 1920 tarihinde 97 oy alarak seçimi kazand1 (TBMM Arşivi, Tercüme-i Hal Kâğıdı, Şahsi Dosya No: 24). 22 Nisan 1920 tarihinde de Müftü Yusuf Talat Efendi'nin yerine seçimleri kazandığ 1 onaylanmıştır (TBMM Arşivi, Tercüme-i Hal Kâğıdı, Şahsi Dosya No: 28.). 8 Mayıs 1920'de Meclise katılmıştır.

Mecliste Anayasa, Tasarı, Mali Kanunlar, İçişleri ve Dışişleri Komisyonlarında çalıştı. 1. toplantı yılında Tasarı Komisyonu'nun ve 2. şubenin kâtipliğini yaptı (Çoker, 1980, s. 105). Dâhiliye Vekili Refet Paşa'nın istifa etmesi üzerine Mustafa Kemal Paşa tarafından Adana mebusu Zekai Bey, Niğde mebusu Ata Bey ile birlikte Dâhiliye Vekâletine aday olarak gösterilmiştir. Ancak 21 Nisan 1921'de yapılan seçimde sadece 3 oy almıştır. Oy çoğunluğunun sağlanması için yapılan ikinci seçimde de 9 oy alabilmiş, 112 oy alan Ata Bey seçimi kazanmıştır (Demirel, 1995, s. 310). TBMM çatısı altında birinci grup içinde yer almıştır (Demirel, 1995, s. 120).

Milletvekilliliği sona erince 15 Eylül 1923'te Kayseri Mutasarrıflı̆ına atand. Livaların il hâline getirilmesi ile 26 Kasım 1923'te Kayseri Valisi oldu ve 13 Ağustos 1927 tarihine kadar bu görevde kaldı. 14 Ağustos 1927' de Mülkiye Müfettişliğine nakledildi. 1 Eylül 1929 tarihinde de Mülkiye Baş Müfettişi olarak görevlendirilmiş ve 9 Ocak 1933 tarihinde emekli olana kadar bu görevde kalmıştır (E.S.G.M.A., Memuriyet Hizmet Cetveli, Ali Vefa SEYHANLI, Şahsi Dosya). 1 Şubat 1933 tarihinde dâhiliye vekâletinden 164 lira emekli maaşı almaya başlamıştır (E.S.G.M.A., Emekli Maaş Bordrosu, Ali Vefa SEYHANLI, Şahsi Dosya, 31.1.1933). Emekli olduktan yaklaşık 20 yıl sonra 21 Eylül 1953'te vefat etmiştir. Evlidir ama çocuğu olmamıştır (Çoker, 1980, s. 106). Vefatından sonra emekli maaşı İçişleri Bakanlığı tarafından 1 Ekim 1953 tarihinde eşi Emine Firdevs Seyhanlı'ya bağlanmıştır (E.S.G.M.A., Yetim Maaşlarına Mahsus Bordro, Ali Vefa SEYHANLI, Şahsi Dosya, 17.11.1953, Ek: 2). 


\section{I. II. Ali Vefa (SEYHANLI) Bey'in Faaliyetleri}

Ali Vefa Bey, Menhubat Komisyonları Kanunu müzakeresi hakkında 15.11.1338(1922) tarihindeki oturumda 3. Madde hakkında söz almıştır.

Menhubat Komisyonları Kanunun 3. maddesine göre "İşbu komisyonlar her mahailin idare ve belediye meclisleri azası tarafindan, erbab-ı vukuf meyanında intihab olunur. İdare ve belediye meclisleri azası işbu komisyonlara âza olmaz." (T.B.M.M. Z.C., 1960, s. 519).

Ali Vefa Bey: " .. Kaymakamlar hem menhubat komisyonları hem de Meclis$i$ idarede riyaset ettiğine nazaran bunların ikisinde de bulunması doğru değildir. Gerçi mazbata muharriri Beyefendi, verilecek talimatta bunlar zikredilecek, demiş ise de talimat kanun kuvvetinde olmadiğından bunun kanunda zikredilmesini teklif ediyorum ve buna dair bir takrir veriyorum." (T.B.M.M. Z.C., 1960, s. 523).

Ali Vefa Bey'in bu teklifi kabul edilmemiş, mazbatada yazıldığı gibi olması uygun görülmüştür.

Kanun hakkında uzun süren sert tartışmalar yaşanmıştır. Kanun maddeleri daha sonra 13.11.1338(1922) tarihinde görüşülmeye başlamış ve uzun tartışmalardan sonra Yunanlılardan tahsis olunan mahallerde menhubat komisyonları kurulmasına dair kanun 18.11.1338(1922) tarihinde kabul edilmiştir (T.B.M.M. Z.C., 1960, s. 561).

\section{II. Halil İbrahim (ÖZKAYA)}

\section{II. I. Halil İbrahim (ÖZKAYA) Bey'in Biyografisi}

1892'de (1308) Antalya'da doğdu. Belediye Hekimi Mehmet Bey'in ve Nimet Hanım'ın oğludur. İlk ve orta öğrenimini Antalya Rüştiyesi ve Konya İdadisi'nde tamamladı (TBMM Arşivi, Tercüme-i Hal Kâğıdı, Şahsi Dosya No: 25, Ek: 3). 25 Kasım 1909'da İstanbul Üsküdar-Selimiye Vakıf Mektebi'nde öğretmen olarak çalışmaya başladı. Öğretmenlik görevini yaparken Darülfünun Hukuk Şubesine devam ederek Temmuz 1914'te mezun oldu.

I. Dünya Savaşı seferberliğinde 9 Ağustos 1914 'te yedek subay adayı olarak talimgâha alındı. 19 Ağustos 1915'te yedek asteğmen rütbesiyle Çanakkale ve Kafkas Cephelerinde savaşa katıldı. Bu arada 1 Mayıs 1917' de 
yedek teğmenliğe yükseltildi. 8 Kasım 1918'de terhisinden sonra Antalya'ya gelerek avukatlık yapmaya başladı. 1 Aralık 1919'da Darülhilafe Medresesi Müdürlügüne getirildi. Avukatlık ve öğretmenlik yaptığ1 sırada yeni teşekkül eden Antalya İhtiyat, Zabitan ve Münevveran Cemiyeti Reisliğinde ve Antalya Müdafaa-i Hukuk Cemiyetinde aktif üye olarak Millî Mücadele'ye katıldı. Bu sırada İtalyanlar tarafından vurulan Ölü Haşmet için kurulan muhtelif tahkik komisyonu azalığında bulundu (E.S.G.M.A., Memuriyet Hizmet Cetveli, Halil İbrahim ÖZKAYA, Şahsi Dosya, 18.2.1941).

TBMM'nin 1. Dönemi için yapılan seçimlerde 91 oy aldı. Antalya Milletvekili olarak 8 Mayıs 1920'de Meclis' te hazır bulundu. İktisat, Dışişleri, Bütçe, Adalet, Anayasa ve Dilekçe komisyonlarında ve Memurin Muhakematı Tetkik Kurulunda çalıştı. 1. toplantı yılında Dilekçe, 2. yılında Adalet komisyonlarının kâtipliğini, 2. ve 3. yılda İktisat Komisyonu'nun sözcülüğünü yaptı (TBMM Arşivi, Tercüme-i Hal Kâğıdı, Şahsi Dosya No: 25). 9 Mart- 10 Mayıs 1923'te El-Cezire (Kuzey Irak) İstiklal Mahkemesi Savcılığı görevinde bulundu (Ayrıntılı bilgi için bkz. Demirel, 1995, s. 461462).

Milletvekilliğinin sona ermesiyle birlikte Antalya'ya dönerek avukatlık mesleğine devam etti. 20 Ocak 1924'ten itibaren yeni açılan Ticaret Okulu'nda hukuk derslerine girmeye başladı. Bu arada İl İdare Heyeti'ne seçildi. 9 Mayıs 1927'de Ticaret Okulu'nun kapatılması üzerine Adliye Vekâletinden bir hâkimliğe tayinini istemesiyle 1 Haziran 1927'de Çay ilçesi Sulh Hâkimliğgi'ne atandı. 25 Aralık 1928 tarihinde görevinde ayrılarak bir gün sonra 26 Aralık 1928' de Sandıklı İlçesi Hukuk Hâkimliği'ne nakledildi. 9 Şubat 1930 tarihinde bu görevden istifa suretiyle ayrılarak Antalya'da avukatlığa döndü. 30 Aralık 1930'da Tokat, 6 Mayıs 1934'te Amasya, 16 Aralık 1934'te Muğla, 12 Nisan 1937'de Niğde Maarif Müdürü olarak görevlendirildi. 29 Kasım 1939 tarihinde Niğde'deki görevinden ayrıldı. 30 Ocak 1939'da atandığı Diyarbakır Maarif Müdürlüğü'nden 9 Şubat 1941'de ayrıldı (E.S.G.M.A., Memuriyet Hizmet Cetveli, Halil İbrahim ÖZKAYA, Şahsi Dosya, 18.2.1941). 26 Şubat 1941 tarihinde de emekliye ayrıldı (E.S.G.M.A., Emekli Maaşı Bordrosu, Halil İbrahim ÖZKAYA, Şahsi Dosya, 26 Şubat 1941).

Antalya'ya dönerek avukatlık yapmaya başladı. İl Genel Meclisi'ne Elmalı üyesi olarak seçildi. $1947^{\prime}$ de Antalya noterliğini üstlendi. 10 yıl bu 
görevde kaldıktan sonra yaş haddinden emekliye ayrılmasıyla Ankara'ya gelerek yerleşti. Ölümüne kadar avukatlık yaptı. 26 Ocak 1972'de öldü. Cebeci Asri mezarlığında toprağa verildi. Evli olup 4 çocuk babasıydı. Ayrıca Fransızca biliyordu. Hukuk ve iktisat alanlarında uzmandı (TBMM Arşivi, Tercüme-i Hal Kâğıdı, Şahsi Dosya No: 25).

Oğullarından Mehmet Şükran Özkaya, 1961- 1980 döneminde Cumhuriyet Senatosu Tabii üyesi olarak TBMM'de bulunmuştur (Çoker, 1980, s. 107-108).

\section{II. II. Halil İbrahim (ÖZKAYA) Bey'in Faaliyetleri}

Halil İbrahim Bey milletvekilliği süresinde $\mathrm{TBMM}^{\prime}$ de aşağıda yer alan hususlar hakkında söz almış ve çalışmalarda bulunmuştur. Halil İbrahim Bey, dahiliye, maliye, hukuk, askeri, eğitim ve kültür konularında faaliyetlerde bulunmuştur.

*Yabanabad Kaymakamı Ali Rıza Efendi'nin Ailesine Maaş Bağlanması

*Idare-i Kura ve Nevahi Kanunu

*Mükellefiyeti Nakliye-i Askeriye Vergisi Kanunu

*1338(1922) Senesi Emniyet-i Umumiye Bütçesi

*Maliye Vekâleti Bütçesi

*Ordu Maaş, Seferberlik ve Cephe Zamları Kanunu

*Askeri Tekaüt ve İstifa Kanununa Müzeyyel Kanun

${ }^{*}$ Hryanet-i Vataniye Kanunu

*Divan-1 Temyiz-i Askeri Kanunu

*Zabıt Ceridelerinin Çoğaltılıp Dağıtılması

*Tedrisat-1 İptidaiye Kanunu (Ayrıntılı bilgi için bkz. Sarıüzel, 2009, s. 27-41). 


\section{III. Hamdullah Suphi (TANRIÖVER)}

\section{III. I. Hamdullah Suphi (TANRIÖVER) Bey'in Biyografisi}

1886'da (1301) İstanbul-Aksaray Horhor'daki Suphi Paşa Konağı'nda doğdu (Çoker, 1980, s. 109-111). Hamdullah Suphi'nin baba tarafından fasılasız şekilde tespit edilen şeceresi şöyledir.

1. Bursa ulemasindan Abdullatif Efendi

2. Abdurrahman Efendi

3.Eşşeyh Elhac Abdulbaki Efendi

4. Şeyh Ahmet Necip Efendi

5. Abdurrahman Sami Paşa (1792-1881)

6. Abdullatif Suphi Paşa (1881-1886)

7. Hamdullah Suphi Tanriöver (1885-1966) (Seraslan, 1995, s. 4).

İlköğrenimini Kısıklı, Altunizade ve Numune-i Terakki Okullarında yaptı. 1895 'te padişah iradesi ile parasız yatılı olarak Galatasaray Sultanisi'ne kaydedildi. Hamdullah Suphi ağabeyleri Yusuf Kamil Bey, Kerim Bey, Abdülvahap Bey ve Hüseyin Bey'den sonra irade-i seniyye ile Galatasaray Sultanisi'ni devlet hesabına parasız olarak bitirerek 1904'te Türkçe bölümünden mezun oldu. Hamdullah Suphi okul çağlarında düzenli giyinen, iyi konuşan bir öğrenci olarak dikkati çekmiştir. Onun fikri yönden gelişmesinde, o dönem hemen hemen bütün Türk gençlerini etkileyen büyük vatan ve hürriyet şairi Namık Kemal'in etkisi büyük olmuştur (Tevetoğlu, 1986, s.28-32).

Eğitim hayatı sona erince 1904 'te İstanbul Şehremaneti Tercümanlığı' nı üstlendi. 1905'te Reji İdaresi (Tütün Tekeli) Tercüme Kalemi'ne girdi. Fakat idarenin kozmopolit havasından rahatsız olarak istifa edip 1907'de Defter-i Hakani Nezareti (Tapu ve Kadastro) yazı işleri kalemine geçti. 1908'de Ayasofya Rüştiyesi'nde Fransızca ve medeni bilgiler dersi vermeye başladı (Çoker, 1980, s. 109-111). Yaşadığı dönemde giyimi, düşünceleri ve hitabet gücüyle çevresindeki insanları etkileyen değişik bir kişilikti. O dönem öğrencilerinden Hidayet Reel okulun diğer hocalarından farklı olan genç öğretmenleri Hamdullah Suphi' den çok etkilendiklerini ifade ederek, şöyle anlatmaktadır: "Beş altı ay bize hürriyetçi, medeniyetçi, milliyetçi atmosfer içinde telkinlerde bulundu. Hayat nedir, sanat nedir, 
ahlak nedir; henüz gelişmemiş dimağlarımızın kavrayabileceği yollardan anlattı." (Reel, Şubat 1967, s.47).

Öte yandan Hamdullah Suphi Bey'in gözde işi yazarlık idi. Ancak güzel konuşma dalında ustalaştı. Şiirleri önce Şura-yı Ümmet'te, sonra da Servet-i Fünun, Resimli Kitap, Musavver Muhit, Resimli Roman ve başka gazete ve dergilerde yayımlandı. Ayrıca Hikâyeler ve Davul adlı dergide mizah yazıları yazdı.

Öğretmenlik hayatına 1910'da İstanbul Öğretmen Okulu'nda Türkçe ve Eğitim Bilimi öğretmenliğine atanarak devam eden Hamdullah Suphi Bey, 1913'te Darülfünun Edebiyat Fakültesi'nde Türk Edebiyatı ve Eğitim Bilimi müderrisi oldu. Bir süre sonra eğitim bilimi dersini bırakarak konusu, Türk-İslam, Güzel Sanatlar Tarihi olan Estetik dersini okutmaya başladı (Çoker, 1980, s. 109-111). Öğrencilerin Türk ve Doğu kültüründen uzak tamamen Batı kültürü ve tarihine yoğunlaştırıldıklarını görmesi onun Türk-İslam Güzel Sanatlar dersine yönelmesine neden olmuştur. Derslerde Roma, Yunan, Gotik ve Rönesans varken Türk, İran ve Arap dünyasının olmamasını yadırgamıştır. Derslerde bu konuları nasıl işleyeceğini öğrencilerine şöyle anlatmaktadır: "Haftada iki dersiniz var. Birinde sizi İstanbul'da dolaştıracağım. Cetlerin yadigârı olan eserleri birer birer ziyaret edeceğiz. Onların teşkil ettiği millî sanatı, medeniyeti parça parça anlatacağım. Roma ve Bizans eserleriyle bizimkiler arasında mukayese yapacağım. Diğer derslerimizde ise ziyaret ettiğimiz abidelerin hususiyetlerini yazdıracă̆ım." (Tanrı̈ver, Ocak1957, s. 485).

Darülfünun'da yaptığı derslere ilgi çok büyüktü hatta başka sınıflardaki öğrenciler de dersine katılıyorlardı. Derslerine olan ilgiyi kendisi şöyle ifade etmektedir: “Talebem Beyazıt Meydanı'nda yüzü aşıyor. Divanyolu'nda 350-400'e ulaşıyor, Sultanahmet Meydan'nda ise, bir miting halini alıyordu." (Baydar, 1968, s. 41). Darülfünun'da derslerine girdiği öğrenciler arasında daha sonra isimlerini tüm Türkiye'nin duyacağı, Reşat Nuri Güntekin, İsmail Hakkı Uzunçarş1ll, Burhanettin Devellioğlu gibi isimlerde vardı (Başar, 2004, s. 73).

Memleketin içinde bulunduğu şartlardan dolayı çok sevdiği öğretmenlik mesleğine son vererek daha siyasi meselelerde görevler almaya başlamıştır. Trakya ve Edirne'nin Osmanlı egemenliğinde kalmasını istemek ve Bulgar zulmünü Avrupa'ya anlatmak üzere oluşturulan kurul üyeliğine seçildi. Heyet'in sözcüsü konumunda olan Hamdullah Suphi 
heyet üyeleriyle birlikte 13 Ağustos-3 Eylül 1913 tarihleri arasında Roma, Paris ve Roma gibi Avrupa'nın önemli siyasi merkezlerini gezmiştir (Bıyıklığlu, 1955, s. 71). Başarılı propaganda çalışmalarından sonra yurda dönen heyet kendiliğinden dağılmıştır.

Hamdullah Suphi Bey, daha sonra dönemin önemli kurumlarından biri olan Türk Ocaklarının genel başkanlığı görevini üstlenmiştir. Hamdullah Suphi'nin başkanlığında 1911-1931 yıllarında Türk Ocağı, ilim, kültür ve sanat merkezi hâline gelmiştir. Şartların el verdiği ölçüde yenilikçi ve milliyetçi bir gençliğin yetiştirilmesine çalışılmıştır. Millı̂ heyecanla Çanakkale'de savaşan Türk askerlerinin başarısında da Türk Ocağının payı büyüktür. Çanakkale' de millî hassasiyetleriyle savaşan Tük askeri ve onlara bu millî heyecanı kazandırmakta yardımcı olan Türk Ocakları için Ferit Cansever şunları söylemektedir: "Çanakkale'de mağlup olan İngilizler, mağlubiyetlerinin mühim sebebini de ocağın Türk ordusuna aşılamış olduğu yüksek milliyetperverlik ve vatanseverlik hislerinde buluyordu ki bu mesainin büyük kısmı değil hemen hemen hepsi merhum Hamdullah'ın eseri idi." (Cansever, Şubat 1967, s. 26). Hamdullah Suphi Bey, Türk Ocaklarının kapatılmasına kadar görevini sürdürmüştür.

Savaş sonrası İstanbul'un durumu tüm milliyetçiler gibi Hamdullah Suphi Bey için de tahammül edilemez haldeydi. Bu duruma çok içerleyen Hamdullah Suphi Bey'in o sıralarda ki durumunu Ord. Prof. Kazım İsmail Gürkan şöyle ifade etmektedir: "Birinci dünya Savaşı Mütarekesi çok sevdiğ $i$ İstanbul'un üzerine kâbusunu kurduğu zaman üniversitenin en genç hocasi ve Türk Ocağının Reisi Hamdullah Suphi Bey tek tesellisini akşamlarn etrafina toplanan gençlerle bu inci şehirdeki sanat eserlerini gezmekte, onları çocuklara tantmakta buluyordu." (Cumhuriyet Gazetesi, 15 Haziran 1966). Ancak İstanbul' da Millî Mücadele için yapabilecekleri çok kısıtlıydı.

Millî Mücadele'ye inanmış aydınların çoğunun yaptığı gibi Hamdullah Suphi de Millî Mücadele'nin kalbi olan Ankara'ya gitmek istemektedir. İstanbul' da kalması diğer vatanperver aydınlar için olduğu gibi onun içinde çok tehlikeli bir hal almıştır. İngilizler tarafından Malta' ya gönderilmek için arananlar arasında kendisi de vardır. Türk Ocağı başkanı olmak, İstanbul mitinglerinde işgali şiddetle protesto etmek, Kuva-yı Milliye'yi desteklemek, Misak-1 Millinin kabulünü istemek, sarayı ihanetle itham etmek arananlar listesine girmesi için yeterli sebeplerdi (Seraslan, 1995, s. 84). 
İngilizlerden saklanmak için 16 Mart 1919 tarihinde Burhanettin Develioğu'nun evine sığınıyor, ertesi gece de ocak arkadaşları Hasan Dündar' ın evinde saklanan Hamdullah Suphi o gecenin sabahında Üsküdar, Şamandıra yolu üzerinden Ankara harekâtına katılmak üzere evden ayrilıyor (Develioğlu, Şubat 1967, s. 13).

Hamdullah Suphi'nin Ankara'ya ulaşması Mustafa Kemal başta olmak orada bulunan vatanseverler tarafından mutlulukla karşılanmıştır. Enver Behnan Şapolyo, Yusuf Akçura, Ahmet Ağaoğlu, Reşit Galip, Vasıf Çınar, Mustafa Necati, Veled Çelebi, İzzet Ulvi, Besim Atalay, Tunalı Hilmi gibi Türk Ocaklı milliyetçi aydınlar da Ankara'ya ulaşırlar (Şapolya, Temmuz 1966, s. 800).

Hamdullah Suphi Ankara'ya geldikten kısa bir süre sonra Meclis açlır. Hamdullah Suphi Bey, Mustafa Kemal Paşa'nın Meclisi açtığı günü şöyle anlatmaktadır: "Güneşli bir günde 23 Nisanda Meclisi açtı... Onun ilk nutkunu rutubete bırakılmış bir sünger gibi iliklerime kadar içerek dinledim. Onu dinledikten sonra reisimizi bulduğumuzu anladım. Memleketin ve kendimizin talihimizi ona biraktık. Onun emri altında kazazede tekne, denizlere ve firtınalara ve büyük meçhule doğru yeniden açıllyordu." (Tanrı̈öer, 1987, s. 175). Meclis açılmıştı ancak hükümetin kurulamaması nedeniyle işleri yürütmek üzere Muvakkat İcra Heyeti seçilir. Seçilen yedi kişiden biri de Hamdullah Suphi' dir. Bu görevi 3 Mayıs 1920 tarihinde hükûmet kuruluncaya kadar devam eder (Seraslan, 1995, s. 90). Milletvekilliği sırasında iki idari görev daha yapmıştır. Biri Maarif Vekilliği diğeri ise milletvekilliği görevine devam ederken yürüttüğü Matbuat ve İstihbarat Umum Müdürlüğü'dür.

Millî Mücadelenin ilk dönemlerinde, yetişmiş eleman sıkıntısı devleti zor durumda birakmaktadır. Bu nedenle milletvekilleri ikinci bir idari görevle vazifelendirilmekteydiler. Hamdullah Suphi de 7 Haziran 1920' de Matbuat ve İstihbarat Umum Müdürlüğü görevine başlamış, 19 Ağustos 1920'de 74 gün sonra görevi sona ermiştir (İskit, 1943, s. 218-220). Bu görevde çok kısa kalmasına rağmen başarılı olmuştur. Yurt dışında istihbarat merkezleri açmış, irşad adını verdiği propaganda programını Anadolu Ajansı ve Hâkimiyet-i Milliye aracılığıyla yapmış, Yunan mezalimini Türkçe ve yabancı dilde resimli kitaplar bastırarak duyurmaya çalışmıştır (İskit, 1943, s. 228-230).

Hamdullah Suphi, iki kez Maarif Vekili olarak görev yapmıştır (Maarif Vekilliği dönemi ile ilgili Ayrıntılı bilgi için bkz. Güven, C., ve Boyraz, 
E. Z., Haziran 2016, s. 290-313). Dr. Riza Nur'dan sonra TBMM'nin ikinci Maarif Vekili olarak 14.12.1920 tarihinde göreve başlamış, 11 ay 8 gün görev yapmıştır. İkinci kez ise 4.3.1925'te göreve başlamış, 9 ay 16 gün görev yapmıştır. Böylece 1 yıl, 8 ay, 24 gün Maarif Vekilliği görevinde kalmiştır (Tevetoğlu, 1986, s.158-159).

Maarif Vekâleti'nin 8 Mart 1923 tarihli genelgesinde: “Cemiyet hayatında, dünya ve ahiret cezaları korkusundan doğan ahlak yerine, hürriyet ve nizamın telifine istinat eden hakiki ahlak ve fazilet hâkim kılmak" (Tanör, 2006, s. 311). hedefleri yer alıyordu. Hamdullah Suphi de hedefi Batlılaşma ve iktisadi gelişme olan millî ruha sahip gençler yetiştirmek için çalışmıştır (Özodaşık, 1999, s. 149-150. “Bizim mekteplerimizde esas izleyeceğimiz amaç çocuklarımızı kendi milletlerinin köküne irca etmektir. Mazilerine sadık kılmaktır." (Kozanoğlu, 2000, s. 87). sözleriyle maarifin amacının millî hassasiyetleri olan gençler yetiştirmek olduğunu ifade etmektedir. Yeni nesillerin iktisadi anlamda da çok iyi eğitilmeleri gerektiğini İzmir İktisat Kongresinde yapmış olduğu konuşmada şöyle ifade etmektedir: "Yeni hükümetimizin bütün esaslar, bütün programlarn iktisat programmdan çıkmalıdır. Onlara o surette ilim ve irfan vermeliyiz ki âlem-i ticaret ziraat ve sanatta ve bütün bunlarn faaliyet sahalarnda müsmir olsunlar, müessir olsunlar, faal olsunlar. Binaenaleyh Maarif programımız, gerek iptidai tahsilde, gerek orta tahsilde verilecek bütün şeyler, bu nokta-i nazara göre olmalıdır." (Cumhurbaşkanları, Başbakanlar ve Millî Eğitim Bakanlarının Millî Eğitimle İlgili Söylev ve Demeçleri, 1946, s. 11). Darülfünun'a yaptığı bir ziyaretinde gençlere ne kadar güvendiğini ve gençlerden beklentisini şu cümlesiyle ifade etmektedir: "Cumhuriyeti kuranlar Cumhuriyetçi yetiştirmeyi sizden bekliyor." (Akyüz, 1982, s. 223). Hamdullah Suphi'ye göre millî eğitimin amacı, batılılaşma ve iktisadi kalkınmayı hedef edinmiş millî ruha sahip gençler yetiştirmekti. Bu hedefler doğrultusunda iki dönem yaptığı Maarif Vekilliği süresinde elinden gelenin en iyisini yapmaya çalışmıştır.

Maarif Vekilliği döneminde dikkat çeken en önemli çalışması şüphesiz İstiklal Marşı'nın millî marş olarak kabul edilmesidir. Millî bir marş yazılması için TBMM tarafından bir yarışma düzenlenmiş ancak Mehmet Akif, yarışmada para ödülü olduğu için yarışmaya katılmayı uygun bulmamıştır. Hamdullah Suphi, millî şairi nasıl ikna ettiğini şöyle anlatmaktadır: "Mehmet Akif Bey, kazanacak şaire nakdi bir mükâfat vaat edildiği için bu müsabakaya iştirak etmemişti. Ben ona şahsen ayruca müracaat ettim. Ve bize 
millî bir marş temin edecek şairin bir para cazibesine kapılmaktan çok uzak olduğunda kimsenin tereddüt etmeyeceğini kendisine temin ettim. $O$ da bildiğimiz marşı yazarak bize gönderdi." (Tanrı̈ver, 26 Aralık 1947, s. 9). Mecliste uzun görüşmelerden sonra 12 Mart 1921 tarihinde İstiklal Marşı kabul edilmiştir (Meclisteki görüşmeler için bkz. T.B.M.M. Z.C., 1958, s. 85-90). Hamdullah Suphi Bey, İstiklal Marşı'nı "Bu marş Anadolu mücadelesinin mühim bir sahifesidir." (Tanrı̈̈ver, 26 Aralık 1947, s. 9) diye tanımlamaktadır. Balıkesir Mebusu Beşir Bey, Mecliste Hamdullah Suphi Bey'in marşı kürsüye çıkarak okumasını teklif etmiştir. Hamdullah Suphi Bey, o anı şöyle anlatmaktadır: "Hayatımda nadir duyduğum bir heyecanla Mehmet Akif'in şiirini okudum. Onu ezici bir ekseriyet ayakta dinledi, zaten o kendi gönlünde bu şiirin lehine kararını vermiş̧i. Bu şiirin nasıl alkışlandığını size tarif etmem müşü̈ldür." (Tanrı̈̈ver, 26 Aralık 1947, s. 9). Şiirin okunmasından sonra herkes Mehmet Akif'i tebrik ediyordu. Üstadın cevabi: “Biz yazdık ama oğlan da çok güzel okudu!" (Gürkan, Şubat 1967, s. 19) oldu. Millet Meclisi'nin, hazırladığı ordular ve kanunlarla düşmanı yenmeye çalıştığ 1 mücadele yıllarında halka Millî Mücadelenin heyecanını verecek İstiklal Marşı'nın yazılmasında ve kabul edilmesinde Hamdullah Suphi Bey'in çok büyük emeği vardır.

Bir ömür boyunca Türklük için atan kalbi 10 Haziran 1966 günü saat 21.35 'de gelen bir krize dayanamaz ve hayata gözlerini yumar. Cenazesi 12 Haziran 1966 günü ordunun düzenlediği bir törenle kaldırılır. Önce Beyazıt Camiinde kılınan cenaze namazının ardından Türk bayrağına sarılı tabutu İstanbul Üniversitesine götürülerek burada da bir tören düzenlenir. Hamdullah Suphi Bey'in Merkez Efendi Mezarlığındaki mezarı başında Ord. Prof. Dr. Zeki Velidi Togan, Behçet Kemal Çağlar, Ziyaeddin Babakurban, Dr. Metin Alyanak ve oğlu Aldemir Alyanak tarafından şahsiyeti hakkında hararetli konuşmalar yapılır (Seraslan, 1995, s. 163-164).

\section{III. II. Hamdullah Suphi (TANRIÖVER) Bey'in Faaliyetleri}

Hamdullah Suphi Bey Birinci TBMM'nde vekil olduğu süreçte Muvakkat İcra Heyeti üyeliği, Matbuat ve İstihbarat Umum Müdürlüğü ve Maarif Vekilliği gibi idari görevlerde bulunmuştur.

Hamdullah Suphi'nin Maarif Vekilliği, Türk tarihinin en zor şartlarının yaşandığı maddi imkânsızlıkların olduğu yıllara rastlar. O şartlarda 
yapılabilecek en iyi şeyleri yapmıştır. 15 Temmuz 1921'de Ankara' da topladığı Maarif Kongresi, Vekâlette kütüphaneler, müzeler, güzel sanatlar olmak üzere 3 şube hâlinde bir Hars Müdüriyeti kurması, Anadolu'daki mekteplere Fransızcayı ders olarak koydurması, siyasi durumun müsaade ettiği ölçüde fesat yuvası olan azınlık okullarını kapatması (Seraslan, 1995, s. 163-164, ayrica bkz. Ergün, 1997, s. 15-20) dönemin zor şartlarında başarıyla gerçekleştirdiği önemli işlerdi.

İstiklal Marşının yazılmasında çok önemli katkıları olmuştur. Mehmet Akif Ersoy'u İstiklal Marşını yazması için ikna etmiştir. Milli Marş seçimi için yapılan toplantıda Meclis kürsüsünden İstiklal Marşını kendisi okumuştur. Çok beğenilen şiir milli marşımız olarak kabul edilmiştir. Müfit Efendi, Hamdullah Suphi Bey' in İstiklal Marşı' nı tekrar okumasını önerdi. Marş Hamdullah Suphi Bey tarafından okundu, resmiyet kazanmış olan marş ayakta ve alkışlar arasında dinlendi (T.B.M.M. Z.C., 1958, s. 88-90).

Marşı kürsüde okuyan Hamdullah Suphi Bey, duygularını şöyle dile getirmektedir: "Hayatımda nadir duyduğum bir heyecanla Mehmet Akif'in şiirini okudum. Onu ezici bir ekseriyet ayakta dinledi, zaten o kendi gönlünde bu şiirin lehine kararın vermişti. Bu şiirin nasıl alkışlandı̆̆ını size tarif etmem müşü̈ldür." (Tanrı̈̈ver, 26 Aralık 1947, s. 9).

Önemli bir hatip olması münasebetiyle Mecliste yaptığı konuşmalar ciltler dolduracak kadar fazladır. Bu konuşmaların pek çoğu mütarekeden sonra vatanın uğradığı felaketler, içkinin yasaklanması, yetimler, malul askerlerin ve öğretmenlerin maddi durumlarının düzeltilmesi, mübadillerin yanlış iskânı, yeniliğe hücum edenlere verdiği cevaplar, sıtma ve benzeri hastalıklar gibi meseleler üzerinedir (Seraslan, 1995, s. 85-90, ayrıca bkz. Sarı̈üzel, 2009, s. 56-79).

\section{IV. Hasan Tahsin (SÜRENKÖK)}

\section{IV. I. Hasan Tahsin (SÜRENKÖK) Bey'in Biyografisi}

1869 'da (1285) Antalya'da doğdu. Buharalı Hacı Ali Efendi'nin ve Ayşe Hanım'ın oğludur (TBMM Arşivi, Tercüme-i Hal Kâğıdı, Şahsi Dosya No: 27, Ek: 4). İlk ve orta eğitimini Antalya Rüştiyesi'nde tamamladıktan sonra 13 Haziran 1886' da aday memur olarak Pozantı Telgrafhanesi'nde devlet hizmetine girdi. 19 Ocak 1887' de Halep PTT Başmüdürlüğünde kâtipliğe 
atand1. 1888-1889 yılları arasinda Burdur, Antalya, Manavgat, Adana ve Tarsus PTT merkezlerinde muhabere memurluğu yaptı. Bu memuriyetleri esnasında kısa sürelerle Antalya ve Tarsus Müdürlüklerine vekâlet etti. 1 Temmuz 1889'da Aksaray, 10 Eylül 1899'da Akseki, 9 Mayıs 1901'de Burdur Merkez Müdürü olarak görevlendirildi. 15 Aralık 1905'te Erzurum PTT Müdürü oldu. Bu görevde iken bir süre başmüdür vekilliği yaptı. 1909 düzenlemesinde İstanbul'a naklini istemekle Genel Müdürlük Sicil Şubesine tayin edildi. 20 Haziran 1918'de isteğiyle emekli olarak Antalya'ya döndü. Millî Mmücadelenin başından itibaren Müdafaa-i Hukuk Cemiyetinde çalıştı.

TBMM'nin 1. dönemi için yapılan seçimlerde Antalya milletvekili olarak 8 Mayıs 1920'de Meclise katıldı. Mecliste Bütçe ve PTT komisyonlarında çalıştı (Çoker, 1980, s. 113-114).

Milletvekilliği sona erince Antalya'ya geldi. Herhangi bir işle meşgul olmadı. Antalya'daki baba ocağında kendisini kitaplara, çocuklarına ve torunlarına vererek 8 yıl geçirdi ve 23 Eylül 1930'da öldü. Evli olup 7 çocuk babası idi. Biraz Arapça bilmekteydi (TBMM Arşivi, Tercüme-i Hal Kâğıdı, Şahsi Dosya No: 27).

\section{IV. II. Hasan Tahsin (SÜRENKÖK) Bey'in Faaliyetleri}

Hasan Tahsin Bey Meclis içerisinde sadece bir kez kürsüye çıkmıştır. 1338(1922) senesi Posta ve Telgraf Müdüriyeti Umumiyesi Bütçesi münasebetiyle 19.6.1338(1922) tarihinde yapılan oturumda söz almıştır. Kendisinin de bu meslekten geldiğini belirterek geçen yıl tab edilen pulların maliyeti ve geçen yılki bütçede oluşan açık hakkında izahat istemiştir (Sarı̈üzel, 2009, s. 80-82).

\section{V. Mustafa (İBRIŞİM)}

\section{V. I. Mustafa (İBRİşi̇M) Bey'in Biyografisi}

Mustafa Bey, 1875 'te (1291) Antalya'da doğdu. Yusuf Ağa'nın ve Fatma Hanım'ın oğludur (E.S.G.M.A., Nüfus Cüzdanı Sureti, Mustafa İBRIŞì, Şahsi Dosya, 10.9.1927, Ek: 5). Öğrenimini Antalya Rüştiyesinde tamamladı. Devlet görevine, memleketi olan Antalya'da Meclis İdare 
Mülâzemeti ile başladı. Daha sonra sırasıyla başkâtip, idare azalığı, encümen daimi azalığı ve belediye reisliği görevlerinde bulunmuştur (TBMM Arşivi, Tercüme-i Hal Kâğıdı, Şahsi Dosya No: 28, Ek: 6). 21 Haziran 1919 tarihinde kurulan Antalya Müdafaa-i Hukuk Cemiyeti'nin kurucuları arasındadır (Çimrin, 2005, s. 65). Müdafaa-i Hukuk Cemiyeti'ni birkaç arkadaşıyla kurup, tam bir özveriyle çalışmıştır.

TBMM'nin 1. Dönemi için yapılan seçimlerde 143 oy alarak Antalya milletvekili seçildi (TBMM Arşivi, Tercüme-i Hal Kâğıdı, Şahsi Dosya No: 28). 8 Mayıs 1920 'de Meclise katıldı. Mustafa Bey'e Ankara' ya gidebilmesi için 7140 kuruş harcırah verilmesi uygun görülmüştür. Ankara'ya hareket ederken harcırahın 5820 kuruşunu Meclis hazinesi tarafından geri ödenmesi kaydıyla Antalya Mahalle-i Maliye sandığından almıştır. Ancak Meclis tarafından geri ödemenin yapılmaması üzerine Umur-1 Mahalliye Müdüriyeti 18.11.1340(1924) tarihinde 1396/388-63 numaralı tezkireyi Başvekâlete göndererek Mustafa Bey'e ödedikleri parayı talep etmişlerdir. Dâhiliye Vekili, Mustafa Bey'in Mahalle-i Maliye sandığından ödünç almış olduğu 5820 kuruşun ödenmesini uygun bulmuştur. Meclis hazinesi tarafından Mustafa Bey'in almış olduğu para geri ödenmiştir (BCA: 030.10.4.23.42, Ek: 7). Tasarı, Tapu-Kadastro ve İçtüzük Komisyonlarında çalıştı. 1. toplantı yılında 1. Şubenin, 3. toplantı yılında İçtüzük Komisyonu'nun kâtipliğini yaptı (Çoker, 1980, s. 115).

Milletvekilliği 1. dönemde sona erince memleketine döndü. Mustafa Bey, emekli olmak için başvurmuştur. Ancak birinci dönemde Meclis'te görev yapan mebusların görev süreleri kanunen iki kat olarak hesaplanmasına rağmen yanlışlık yapılarak Mustafa Bey'in hesap cetveline bir kat olarak işlenmiştir. 20 Mart 1929 tarihinde Dâhiliye Vekâletine bu konuyla ilgili dilekçe yazarak yapılan yanlışlı̆̆ın düzeltilmesini istemiştir (E.S.G.M.A., Dâhiliye Vekâletine Yazdığı Yazı, Mustafa İBRİ̧̧ì, Şahsi Dosya, 20.4.1929, Ek: 8). Gerekli düzenlemeler yapıldıktan sonra gerekli görev süresini doldurarak 24 Mart 1929'da emekli oldu. Ölümünden sonra emekli maaşı eşi Fatma Hanım'a 269 lira, kızı Afife Hanım’a 149 lira olmak üzere bağlanmıştır (E.S.G.M.A., Emekli Maaşı Bordrosu, Mustafa İBRIŞ̧iM, Şahsi Dosya, 1.8.1966).

11 Haziran 1944'te vefat etti. Evli olup, beş çocuk babasıydı (TBMM Arşivi, Tercüme-i Hal Kâğıdı, Şahsi Dosya No: 28). 


\section{V. II. Mustafa (İBRİ̧̧iM) Bey'in Faaliyetleri}

Mustafa Bey Mecliste Tarik Bedeli Nakdisi Kanununa ek kanun layihasının görüşüldüğü 24.6.1338(1922) tarihli oturumda söz almıştır. Ayrica 10 Nisan 1338(1922) tarihinde Hariciye Vekili Yusuf Kemal Bey'in Avrupa'da İtalya Hariciye Nazırı ile yaptığı görüşme ile ilgili sual takriri vermiştir (Sarıüzel, 2009, s. 84-87).

\section{VI. Rasih (KAPLAN)}

\section{VI. I. Rasih (KAPLAN) Bey'in Biyografisi}

1883'te (1299) Antalya'nın Akseki ilçesinde Fakılar mahallesinde doğdu. Şatırzade Mehmet Tahir Efendi ile Tevhide Hanım'ın oğludur. İlk ve orta öğrenimini Akseki İptidai Mektebi ve Rüştiyesinde tamamladıktan sonra 1902' de Konya'ya giderek eski Konya Müftüsü Yalvaçlı Ömer Efendi'den, Arabîye ve Şer'iye dersleri alarak, 1906 yılında müderrislik icazeti aldı. 1906 Eylül'ünde Arapça ve din bilgisini geliştirmek için Misır'a gitti. "Camiülezher" de ve ayrıca Kahire Darülfünunu Edebiyat ve İçtimaiyat Medreselerinde öğrenim gördü. Arapça yazma ve konuşmada uzmanlaştı. 14 Ağustos 1911'de İstanbul'a gelerek Şer'iye Vekâleti şûrâ-y1 evkaf azasından Nevşehirli Hasan Efendi Hoca'dan icazetname aldı (TBMM Arşivi, Tercüme-i Hal Kâğıdı, Şahsi Dosya No: 29, Ek: 9). Aralık ayında Konya İl Genel Meclisinin Antalya üyesi olarak seçildi. 1912 ve 1913 yıllarında Akseki Maarif Encümeni Başkanlığg'nı yaptı. 1914'te Antalya'nın bağımsız liva hâline getirilmesiyle Liva Daimi Encümen üyesi oldu. Bu görevi, 1920 yılına kadar sürdürdü (Çoker, 1980, s. 116).

Rasih Efendi, 1900 yılında daha 17 yaşındayken (Oran, 1997, s. 8) kendisiyle aynı yaşta olan Kızılağaç köyünden Hatice Hanım ile evlendi. Bu evlilikten, 1901'de Fatma, 1903'te Şerife ve 14 Nisan 1906'da Ahmet Zeynel Abidin adında çocukları oldu (E.S.G.M.A., Nüfus Kayıt Örneği, Rasih KAPLAN, Şahsi Dosya, 18.11.1952, Ek: 10).

Sivas Kongresi'nden sonra Anadolu'nun her yerinde olduğu gibi Antalya'da da bazı çalışmalara başlanmıştı. 21 Haziran 1919'da kurulan ve Nazilli'deki Heyet-i Merkeziye'ye bağlı olarak çalışacak olan Müftü Yusuf Talat Efendi'nin başkanlığında kurulan Müdafaa-i Hukuk Cemiyeti'nin 
biri de Rasih Efendi idi (Çimrin, 2005, s. 65). Meclis açılana kadar Müdafaa-i Hukuk Cemiyeti içerisinde çalışmalarını sürdürdü.

TBMM'nin 1. dönemi için 29 Nisan 1920'de yapılan seçimde Antalya milletvekili olarak 8 Mayıs 1920'de Meclise katıldı. Ankara' ya gidebilmesi için 7140 kuruş harcırah alması uygun görülmüş, bunun 5820 kuruşunu geri ödenmesi kaydıyla vilayet hazinesinden almıştır. Vilayetten aldığ 1 para daha sonra Meclis hazinesi tarafından ödenmiştir (BCA: 030.10.4.23.42).

Milletvekilliği görevinde bulunduğu sırada 19 Şubat 1932'de kurulan halk evleri içinde çalışmış 1933'te kurulan Antalya Halk Evi'nin açlışına katılmıştır. Halk evleri kadar köy enstitülerinin de eğitim için çok faydalı olacağına inanan Rasih Kaplan, Aksu Köy Enstitüsü'ne yaptığı ziyaretindeki konuşmasında köylüyü kurtarmak ve bugünün hayat şartlarına adapte edebilmek için Meclis'in aldığı kararla kurulan köy enstitülerinin çok önemli bir görev üstlendiğinden bahsetmektedir (Oran, 1997, s. 9-10). Memleketin geleceğinin eğitimin ellerinde olduğuna inanan Rasih Kaplan, Avrupa ülkelerinden alınan eğitim programlarının memleketin temellerini sarstığını düşünmekteydi. Milletin ruh hâline uygun, bilgi seviyesini yükseltecek bir programla temelleri yeniden kurmak gerektiğine inanıyordu (Kozanoğlu, 2000, s. 85). Rasih Efendi, milletvekilliği döneminde eğitim, sağlık gibi sosyal sorunlarla ilgilenmiş, çözüm üretebilmek için elinden geleni yapmıştır.

Rasih Efendi, Atatürk'e olan bağlılığını hiçbir zaman yitirmemiş, Atatürk'ün ölümünden sonra da CHP çatısı altında çalışmalarını sürdürmüştür. Antalya Halk Evin'de yaptığı bir konuşmasında Atatürk'e olan inancını şu şekilde dile getirmiştir: "Devlet kurma konusunda Türk milleti kadar usta bir millet yoktur. Atatürk ve Inönü'yü devletin başına getirerek Türk milleti bir kez daha bunu ispat etmiştir." (Yeşil Antalya Gazetesi, 1 Nisan 1947).

Milletvekilliği yaptığı dönemde, 4'ü gizli oturumda olmak üzere 49 konuşma yaptı. 5 kanun önerisi verdi. Bunlardan arkadaşlarıyla birlikte önerdiği ikisi, İstiklal Mahkemeleri Kanununun 1'inci maddesine ek kanun (28-26.09.1920) ve öğretmenler ve öğrencilerin askerlikten ertelenmeleri hakkında kanun (100-21.2.1921) kabul edildi.

Rasih Kaplan, 2'nci, 3'üncü, 4'üncü, 5' inci, 6' 'nc1, 8' inci dönemlerde Antalya'dan, 7'nci dönemde Maraş'tan yeniden milletvekili seçilerek 
Meclisteki yerini 14 Mayıs 1950'ye kadar korudu. Meclis'te, kürsüde çok konuşan ve sürekli yurt davalarını savunan renkli bir simaydı.

28 Temmuz 1945 tarihinde öğretmenlik mesleğinde 25 yıllık görev süresini doldurduğu gerekçesiyle Millî Eğitim Bakanlığı'na emekli olmak için başvurmuştur (E.S.G.M.A., Millî Eğitim Bakanlığına Yazdığı Yazı, Rasih KAPLAN, Şahsi Dosya, 18.7.1945, Ek:11). 15 Ağustos 1945 tarihinde Millı̂ Eğitim Bakanlığı tarafından şartları uygun görülerek emekli edildi (E.S.G.M.A., Millî Eğitim Bakanlığı Zat İşleri Müdürünün Dilekçesi, Rasih KAPLAN, Şahsi Dosya, 15.8.1945). Vefatından sonra emekli maaşı hayatta olan tek yakını kızı Fatma Hanım'a bağlanmıştır (E.S.G.M.A., Emekli Maaş Bordrosu, Rasih KAPLAN, Şahsi Dosya, 20.05.1968, Ek: 12).

Milletvekilliği sona erince Akseki'ye döndü. Eşi Hatice Hanım'ın 1949'da ölmesi üzerine 31.1.1952 tarihinde Şerife Hanım ile evlenmiş ama evlilikleri uzun sürmemiş 07.2.1952' de boşanmışlardır (Oran, 1997, s. 90).

Emekli olduktan sonra herhangi bir işle ve politikayla meşgul olmadi. 13 Kasım 1952'de vefat etti (E.S.G.M.A., Nüfus Kayıt Örneği, Rasih KAPLAN, Şahsi Dosya). Akseki mezarlığında toprağa verildi.

\section{VI. II. Rasih (KAPLAN) Bey'in Faaliyetleri}

İrşad, Dışişleri ve Millî Eğitim komisyonlarında çalıştı. Ayrıca Meclis Haysiyet Divanı'nda görevlendirildi (Çoker, 1980, s. 116). 5.10 .1920 tarihinde kurulmuş olan Eskişehir İstiklal Mahkemesine 65 oyla âza olarak seçildi. 19.2.1921 tarihinde İstiklal Mahkemesi kaldırılana kadar bu görevi sürdürdü (Ezherli, 1986, s. 63). İstiklal Mahkemesi üyeliğinde bulunduğu için kırmızı-yeşil şeritli istiklal madalyası almıştır. Bu madalya daha sonra oğlu Ahmet Zeynel Abidin Kaplan'ın isteği üzerine, 1958'de oğluna intikal ettirilmiştir (Oran, 1997, s. 10).

Rasih Efendi, Mustafa Kemal Atatürk'e yakın olan milletvekillerinden biri olmuştur. İnkılâplar konusunda yapılan eleştirilere göğüs geren mebuslardan biri olan Rasih Efendi, din adamı kimliğiyle dini kullanarak yapılan istismarlara karşı mücadele içinde olmuştur. Tekke ve zaviyelerin kapatılması, hilafetin kaldırılması gibi konularda etkili konuşmalar yapmiştır.

Rasih Kaplan Bey milletvekilliği süresinde TBMM'de aşağıda yer alan hususlar hakkında söz almış ve çalışmalarda bulunmuştur. 
* İstihbarat ve Propaganda

* Bursa'nın İşgali

* Lozan Konferansi

* Müskiratın Meni İmal ve İstimali Kanunu

* Menhubat Komisyonları Kanunu

* Saltanatın kaldırılması

* Hryane-i Vataniye Kanunu

* İstiklal Mahkemesi

* Sıhhiye Encümenliği

* Maliye

* Sansür (Sarı̈üzel, 2009, s. 90-108).

\section{Sonuç}

Birinci Dünya Savaşı'ndan sonra İtilaf Devletleri, Osmanlı Devleti ile yaptıkları Mondros Mütarekesine dayanarak Anadolu topraklarını işgal etmeye başladılar. Ancak Türk Milleti'nin azim ve kararlılığını hiç hesaba katmıyorlardı. İstanbul Hükümetinin işgalleri kabul eder tavrı karşısında Anadolu halkı teslim olmayı asla kabul etmemiştir. Mustafa Kemal'in Anadolu'ya ayak basmasıyla birlikte Türk milleti yeniden umutlanmış, kurtuluş temelleri atılmaya başlanmıştır.

Mustafa Kemal Paşa da kurtuluşun sadece ve sadece milletin azim ve kararıyla sağlanabileceğinin farkındaydı. Bu nedenle Millî Mücadeleyi millet adına idare edecek, gücünü Türk Milleti'nden alacak Türkiye Büyük Millet Meclisi 23 Nisan 1920 tarihinde Ankara'da kurulmuştur.

$\mathrm{Bu}$ sırada Anadolu'nun her yeri İtilaf Devletleri tarafından işgal edilirken Antalya da İtalyanlar tarafından işgal edilmiştir. Antalya'nın İtalyan işgaline karşı koymadığı hatta işgalcileri kendi rızalarıyla şehre aldıkları söylense de bu tamamen İtalyanların bir oyununun sonucudur. İtalyanlar diğer işgal güçleri gibi kaba kuvvete başvurmuyorlar, halkın güvenini kazanmaya ve iyi ilişkiler kurmaya çalışıyorlardı. Bu da İtalyanlar ile Antalya halkı arasında sorun yaşanmasını engelliyordu. İtalyanlar, halkı hükümetlerine karşı kışkırtmak ve kendi yanlarına çekmek suretiyle istediklerini alma yolunu seçmişlerdi. Ancak Antalya halkı İtalyanların bu oyunlarına gelmemiş, tüm Anadolu' da olduğu gibi işgale karşı mücadele etmişlerdir. Türk kuvvetlerinin, Anadolu'nun çeşitli yerlerinde mücadele 
etmesi nedeniyle bir de İtalyanlarla uğraşmaması için bilinçli olarak İtalyanlar ile iyi geçinmeye gayret göstermişlerdir.

Anadolu'nun her yerinde olduğu gibi Antalya'da da Müdafaa-i Hukuk Cemiyeti kurulmuştur. Birinci Dönem milletvekillerinin tamamı bu cemiyet altında faaliyet göstermişlerdir. Düşmanların Anadolu'da yaptıkları işgalleri protesto etmek, İtalyanlardan satın aldıkları silah ve cephaneyi batı cephesindeki kuvvetlere göndermek gibi önemli çalışmalarda bulunmuşlardır. Ayrıca İzmir'de faaliyet gösteren Hüseyin Rüştü Bey'in Anadolu gazetesinin Yunanlılar tarafından kapatılması üzerine gazeteyi Antalya'ya taşıyarak Antalya'da Anadolu adıyla yayımlanmasını sağlamışlardır.

Türkiye Büyük Millet Meclisi'nin açılmasına karar verilmesi üzerine yapılan seçimle Rasih Kaplan, Halil İbrahim Bey, Hasan Tahsin, Mustafa Bey, Ali Vefa Bey ve İstanbul'dan kaçarak Ankara'ya ulaşan Hamdullah Suphi Bey milletvekili seçildiler ve 8 Mayıs 1920 tarihinde Meclise katıldılar.

Birinci dönemde Meclise katılan Antalya milletvekilleri genelde yüksek tahsilli kişilerdi. Hamdullah Suphi Darülfünun müderrisliği, Hasan Tahsin PTT müdürlüğü, Mustafa Bey belediye reisliği, Ali Vefa Bey kaymakamlık, Halil İbrahim Bey öğretmenlik ve avukatlık, Rasih Kaplan ise Liva Daimi encümenliği azalığı gibi görevlerini bırakarak Meclise katılmışlardır.

$\mathrm{Bu}$ dönem milletvekillerinden ikisi Hamdullah Suphi Bey ve Rasih Kaplan ön plana çıkmaktadırlar. Hamdullah Suphi Bey, 14.12.1920 tarihinde Meclisin ikinci maarif vekili olarak göreve başlamış ve iki dönem maarif vekilliği yapmıştır. Ayrıca hatipliği ile de ön plana çıkan Hamdullah Suphi Bey, kürsüden yaptığı konuşmalarda çoğu milletvekilini kendine hayran bırakmıştır. En önemlisi ise İstiklal Marşı'nı Mehmet Akif Ersoy'a yazdırarak Mecliste kabul edilmesini sağlamıştır.

Rasih Kaplan ise Eskişehir İstiklal Mahkemesi'nde görev almış, önemli kararlara imza atmıştır. Antalya milletvekilleri arasında en çok kürsüye çıan kendisi olmuştur.

Rasih Kaplan, Hamdullah Suphi Bey ve Ali Vefa Seyhanlı Birinci Grup içinde yer alırken Hasan Tahsin Bey, Halil İbrahim Bey ve Mustafa Bey İkinci Grupta yer almışlardır. İkinci Dönem'de sadece Birinci Gurup üyeleri Rasih Kaplan ve Hamdullah Suphi Meclise girebilmiş, Ali Vefa Bey 26 
Kasım 1923'te Kayseri Valisi olmuştur. İkinci Gurup üyesi milletvekilleri ise Meclise girememiş eski işlerine devam etmişlerdir.

Millî Mücadele'nin karar mekanizmasını oluşturan ve yani Türk Devleti'nin temellerini atan Birinci Türkiye Büyük Millet Meclisi'nin ruhuna uygun olarak Antalya milletvekilleri de ellerinden gelen tüm gayreti göstererek vatana ve millete faydalı olmuşlardır.

Millî Mücadele'nin karar mekanizmasını oluşturan Türkiye Büyük Millet Meclisi verdiği kararlarla gerek Millî Mücadele'nin kazanılmasında gerekse yeni kurulan Türk Devleti'nin temellerinin oluşturulmasında önemli çalışmalar yapmıştır. Türkiye Büyük Millet Meclisi çatısı altında görev yapan Birinci Dönem Antalya milletvekilleri de Meclisin kutsal ruhuna yakışır şekilde ellerinde gelen tüm gayreti göstererek Türk Milleti'nin kalbinde ve Türk Tarihindeki unutulmaz yerlerini almışlardır.

\section{Kaynakça}

\section{Arşiv Belgeleri}

BCA: 030.10.4.23.42.

BCA: 030.10.4.23.42. Ek: 7.

E.S.G.M.A., Dâhiliye Vekâletine Yazdığı Yazı, Mustafa İBRİ่̧iM, Şahsi Dosya, 20.4.1929, Ek: 8.

E.S.G.M.A., Emekli Maaş Bordrosu, Ali Vefa SEYHANLI, Şahsi Dosya, 31.1.1933.

E.S.G.M.A., Emekli Maaşı Bordrosu, Halil İbrahim ÖZKAYA, Şahsi Dosya, 26 Şubat 1941.

E.S.G.M.A., Emekli Maaşı Bordrosu, Mustafa İBRIŞSiM, Şahsi Dosya, 1.8.1966.

E.S.G.M.A., Emekli Maaş Bordrosu, Rasih KAPLAN, Şahsi Dosya, 20.05.1968, Ek: 12.

E.S.G.M.A., Nüfus Cüzdanı Sureti, Mustafa İBRIŞ̧iM, Şahsi Dosya, 10.9.1927, Ek: 5 .

E.S.G.M.A., Nüfus Kayıt Örneği, Rasih KAPLAN, Şahsi Dosya, 18.11.1952.

E.S.G.M.A., Nüfus Kayıt Örneği, Rasih KAPLAN, Şahsi Dosya, 18.11.1952, Ek: 10 . 
E.S.G.M.A., Memuriyet Hizmet Cetveli, Ali Vefa SEYHANLI, Şahsi Dosya.

E.S.G.M.A., Memuriyet Hizmet Cetveli, Halil İbrahim ÖZKAYA, Şahsi Dosya, 18.2.1941.

E.S.G.M.A., Millî Eğitim Bakanlığına Yazdığı Yazı, Rasih KAPLAN, Şahsi Dosya, 18.7.1945, Ek:11.

E.S.G.M.A., Millî Eğitim Bakanlığ Zat İşleri Müdürünün Dilekçesi, Rasih KAPLAN, Şahsi Dosya, 15.8.1945.

E.S.G.M.A., Yetim Maaşlarına Mahsus Bordro, Ali Vefa SEYHANLI, Şahsi Dosya, 17.11.1953, Ek: 2.

TBMM Arşivi, Tercüme-i Hal Kâğıdı, Şahsi Dosya No: 24.

TBMM Arşivi, Tercüme-i Hal Kâğıdı, Şahsi Dosya No: 24, Ek: 1.

TBMM Arşivi, Tercüme-i Hal Kâğıdı, Şahsi Dosya No: 25

TBMM Arşivi, Tercüme-i Hal Kâğıdı, Şahsi Dosya No: 25, Ek: 3.

TBMM Arşivi, Tercüme-i Hal Kâğıdı, Şahsi Dosya No: 27.

TBMM Arşivi, Tercüme-i Hal Kâğıdı, Şahsi Dosya No: 27, Ek: 4.

TBMM Arşivi, Tercüme-i Hal Kâğıdı, Şahsi Dosya No: 28.

TBMM Arşivi, Tercüme-i Hal Kâğıdı, Şahsi Dosya No: 28, Ek: 6.

TBMM Arşivi, Tercüme-i Hal Kâğıdı, Şahsi Dosya No: 29, Ek: 9.

\section{Gazeteler}

Hamdullah Suphi'ye Veda, ( 15 Haziran 1966). Cumhuriyet Gazetesi.

Yeşil Antalya Gazetesi, 1 Nisan 1947.

\section{Resmi Yayınlar}

Cumhurbaşkanları, Başbakanlar ve Millî Eğitim Bakanlarının Millî Eğitimle İlgili Söylev ve Demeçleri, (1946). MEB Yay., Ankara.

T.B.M.M. Z.C., (1958), Devre 1, C. 9, Ankara.

T.B.M.M. Z.C., (1960), Devre 1, C. 24, Ankara.

\section{Kitaplar}

Aksoy, İlhan, (2006). Atatürk İlkeleri ve İnkılâp Tarihi, Ankara.

Akyüz, Yahya, (1982). Türk Eğitim Tarihi (Başlangıçtan 1982'ye), Ankara.

Başar, Erdoğan, (2004). Millî Eğitim Bakanlarının Eğitim Faaliyetleri (1920-1960), İstanbul. 
Baydar, Mustafa, (1968). Hamdullah Suphi Tanrı̈ver ve Anıları, Menteş Yayınları, İstanbul.

Bıyıklığlu, Tevfik, (1955). Trakya'da Millî Mücadele, C. 1, Ankara.

Çimrin, Hüseyin, (2005). Antalya Kent Kronolojisi, Antalya Ticaret ve Sanayi Odası Yay., Antalya.

Çoker, Fahri, (1980). Türk Parlamento Tarihi 1919-1923, C. 3, Ankara.

Demirel, Ahmet, (1995). Birinci Mecliste Muhalefet (İkinci Grup), 2. Bask1, İletişim Yay., İstanbul.

Ergün, Mustafa, (1997). Atatürk Devri Türk Eğitimi, Ocak Yay., 2. Baskı, Ankara.

Erten, Süleyman Fikri, (1996). Millî Mücadele'de Antalya, Antalya Müzesi Yay. Antalya.

Ezherli, İhsan, (1986). TBMM (1920-1986), TBMM Basımevi, Ankara.

Grassi, Fabio L., (2003). İtalya ve Türk Sorunu (1919-1923 Kamuoyu ve Dış Politika), Çev: Nevin Özkan, Durdu Kundakçı, Yapı Kredi Yay., İstanbul.

İskit, Servet, (1943). Türkiye' de Matbuat İdareleri ve Politikaları, İstanbul. Karal, Enver Ziya, (1983, Osmanlı Tarihi, TTK Yay., C. 5, Ankara.

Kozanoğlu, Zeynep, (2000). Vatan, Hürriyet, Ekmek (Birinci Dönem TBMM Tutanaklarından Notlar), AKM Yay. Ankara.

Özodaşık, Mustafa, (1999). Cumhuriyet Dönemi Yeni Bir Nesil Yetiştirme Çabaları (1923-1950), Çizgi Kitabevi, Konya.

Seraslan, Halim, (1995). Hamdullah Suphi Tanrı̈ver, Türk Kültürü Araştırma Enstitüsü, Ankara.

Tanör, Bülent, (2006). Kurtuluş, Kuruluş, Cumhuriyet Kitapları, 7. Baskı, İstanbul.

Tanrı̈ver, Hamdullah Suphi, (1987). Günebakan, Haz. Fethi Tevetoğlu, Kültür ve Turizm Bakanlığı Yay., İzmir.

Tevetoğlu, Fethi, (1986). Hamdullah Suphi Tanriöver, Ankara.

Tosun, Ramazan, (1994). Türkiye Cumhuriyeti Tarihi (Kuruluş Dönemi), Erciyes Üni. Yay., Kayseri.

\section{Makaleler}

Cansever, Hasan Ferit, (Şubat 1967) "Rahmetli Hamdullah Suphi Tanrı̈ver", TYD., cilt: 6, sayı: 2, Ankara. 
Develioğlu, Burhanettin, (Şubat 1967). "Hamdullah Suphi ile 55 Sene", TYD., C. 6, Sayı: 2, Ankara.

Gürkan, Kazım İsmail, (Şubat 1967). "Hamdullah Suphi Büyük Hatip", TYD., C. 6, Sayı: 2, Ankara.

Güven, C., ve Boyraz, E. Z., (Haziran 2016). "Hamdullah Suphi Tanrı̈ver'in İlk Maarif Vekilliği Dönemi Faaliyetleri”, OPUS, C. 6, Sayı: 10, Ankara.

Reel, A. Hidayet, (Şubat 1967). “Milliyetçi ve Medeniyetçi Lider Hamdullah Suphi Tanriöver", TYD, C. 6, Sayı: 2, Ankara.

Şapolyo, Enver Behnan, (Temmuz 1966). “Millî Mücadele'de Hamdullah Suphi”, Türk Kültürü Dergisi, Sayı: 45, Ankara.

Tanrı̈ver, Hamdullah Suphi, ( 26 Aralık 1947). “İstiklal Marşı”, Kızıl Elma Dergisi, Sayı: 9, Ankara.

Tanrı̈ver, Hamdullah Suphi, (Ocak 1957). “ Reşat Nuri Güntekin”, TYD, sayı: 264, Ankara.

\section{Tezler}

Oran, Nebahat, (1997). Antalya Milletvekili Rasih (Kaplan) Bey'in I. ve II.

Dönem TBMM'ndeki Siyasi Faaliyetleri, Atatürk Üniversitesi SBE, Yayınlanmamış Yüksek Lisans Tezi, Erzurum.

Sarıüzel, Nedim, (2009). Birinci ve İkinci Dönem Türkiye Büyük Millet Meclisinde Antalya Milletvekilleri (Biyografi ve Faaliyetleri), Selçuk Üniversitesi SBE, Yayınlanmamış Yüksek Lisans Tezi, Konya. 


\section{Ekler}

MILLET MECLISI OYESI

24

HAL TERCUMMEST KÅĞIDI ORNEĞ

\begin{tabular}{|c|c|c|c|}
\hline Adı ve Soyadı & All Vefa Seyhanll & Imî rütbesi & - \\
\hline $\begin{array}{l}\text { Babasinm ve } \\
\text { Anasmin ard }\end{array}$ & $\begin{array}{l}\text { Muhammed Naim } \\
\text { Moliha }\end{array}$ & $\begin{array}{l}\text { Mesleki ve işi- } \\
\text { güeü }\end{array}$ & $\begin{array}{l}\text { Miilkiye Meslokinde } \\
\text { I.S. Kaymakam }\end{array}$ \\
\hline $\begin{array}{l}\text { Doğum yeri } \\
\text { ve tarihi }\end{array}$ & $\begin{array}{l}\text { Kabris adas1- Mahsuss } \\
\text { kasabas1 } 1288\end{array}$ & $\begin{array}{l}\text { Yedek Subay ise } \\
\text { subesi ve sicil } \\
\text { No. su }\end{array}$ & \\
\hline Tahsili & Mitlk1ye Mokteb1 & $\begin{array}{l}\text { Evli olup olma- } \\
\text { duğı, kaę cocuğa } \\
\text { bulunduğu }\end{array}$ & Ev11 ģocuksuz \\
\hline Bildiği diller & Az Pransizca ve arapça & $\begin{array}{l}\text { Seçimden evvel- } \\
\text { ki iş durumu }\end{array}$ & Nutasarrifllk \\
\hline thtrsast & - & $\begin{array}{l}\text { Memur olup } \\
\text { olmadığ1 }\end{array}$ & Nutasarrif \\
\hline Eserierì & . & Mebuslukları & 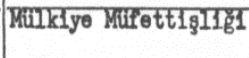 \\
\hline
\end{tabular}

Ilk Büyilk Millet Meclisinden sonra Mutasarr 1hlik ve Valilik yaparak on son memur1yetim olan Miilkıye Baģmilfett1şl1ğınden emekliylm.

All Vofa Seyhanls

\section{Birinc1 Dönem Halterciimesinden :}

3. Bylill.1313 tar1h1nde Suriye V1layet1 Ma1yet memurluğu görev1 ile Devlet h1 ametine katilan mumalloyh surasiyle Su Sehr1, Meo1tözli, Maan, Salt, Monemen, Fin1kiye vo Korkutell kaymakamliklarinda bulunmus ve 8.May1s.1336 tar1h1nde Antalya Kobus luğu 1le Neclise 1ltihak ederek 10.Ağustos.1339 tarihine kadar 1fayl h1zmet etmis ve

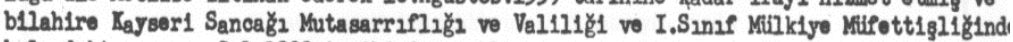
bulunduktan sonra 9.1.1933 tarihinde emekllye çlkarzlmıştır.

Ek 1: Ali Vefa SEYHANLI Tercüme-i Hal Kâğıdı 
Birinci Dönem Türkiye Büyük Millet Meclisinde Antalya Milletvekilleri (Biyografi Ve Faaliyetleri)

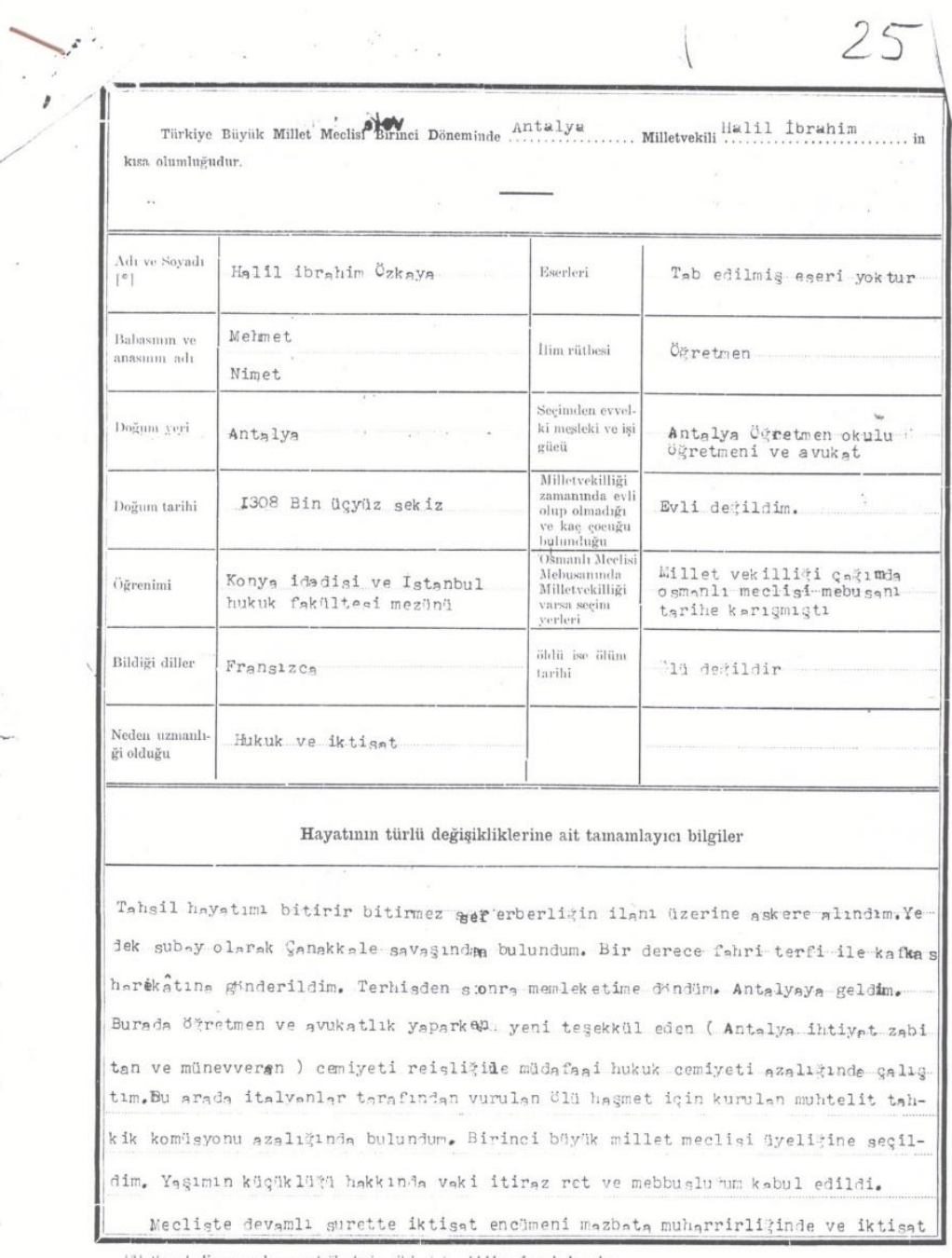

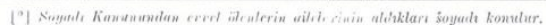

\section{Ek 2: Halil İbrahim ÖZKAYA Tercüme-i Hal Kağıdı}




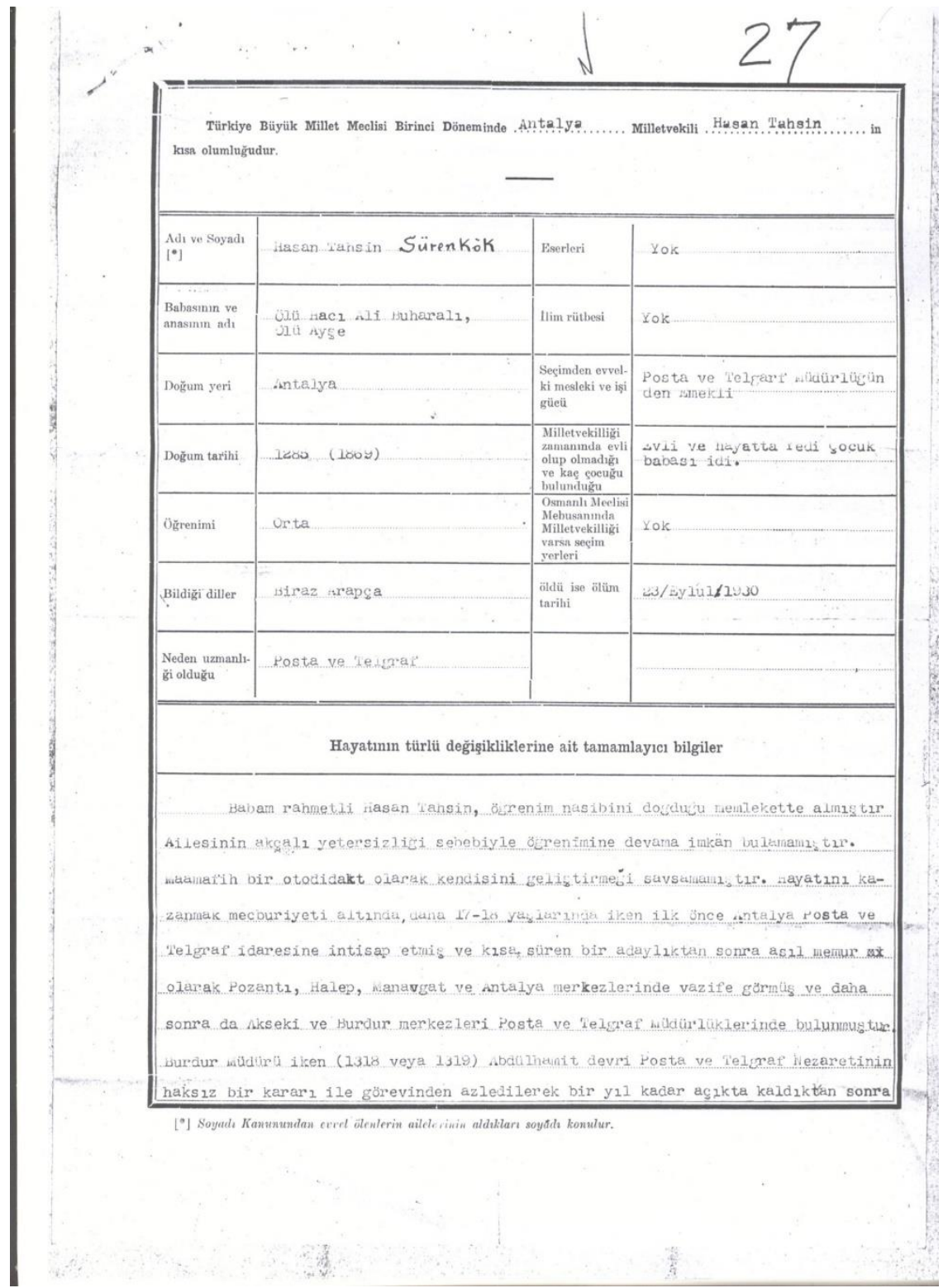

\section{Ek 3: Hasan Tahsin SÜRENKÖK Tercüme-i Hal Kă̆ıdı}


Birinci Dönem Türkiye Büyük Millet Meclisinde Antalya Milletvekilleri (Biyografi Ve Faaliyetleri)

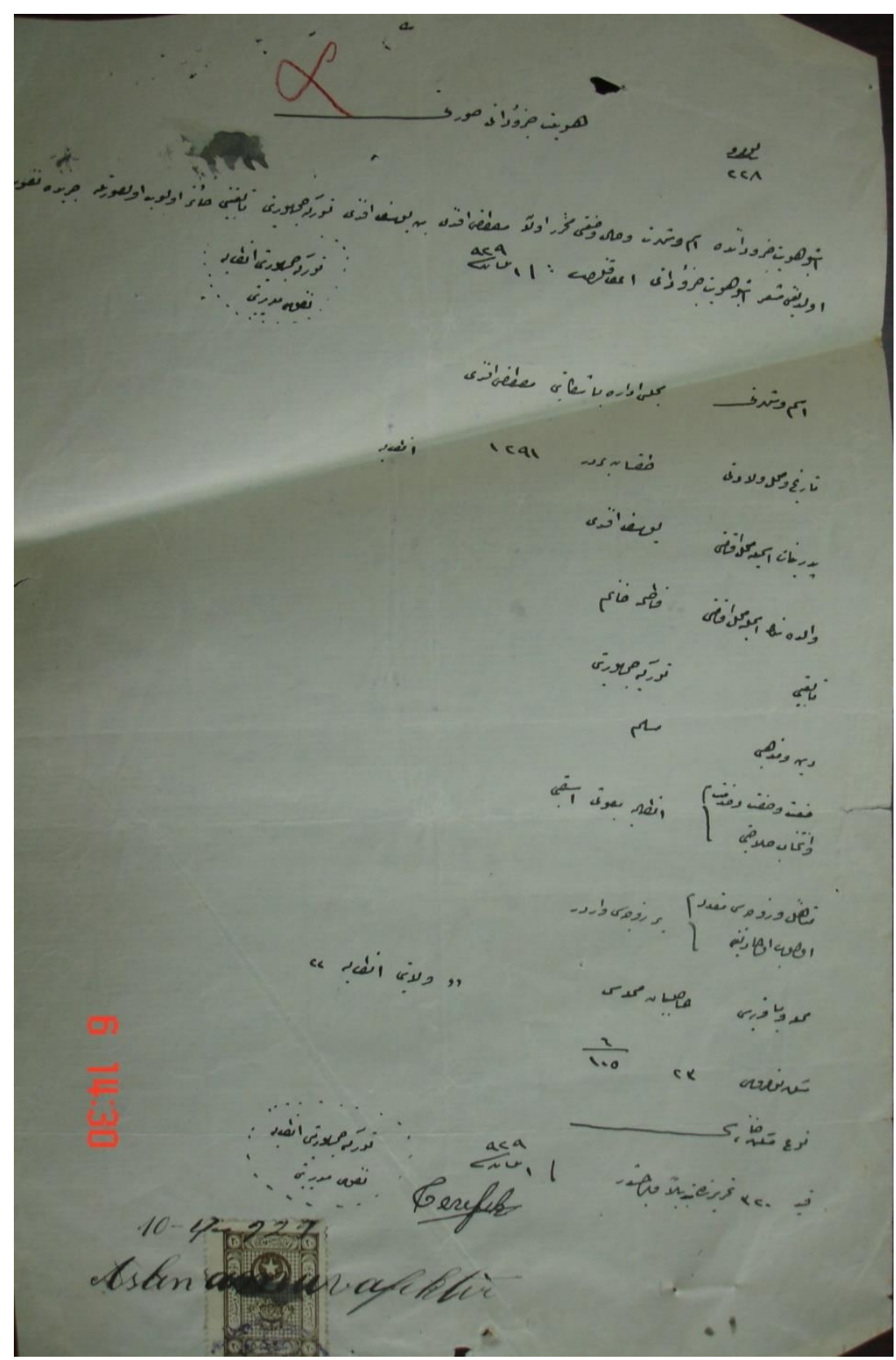

Ek 4: Mustafa İBRişIM Nüfus Sureti 


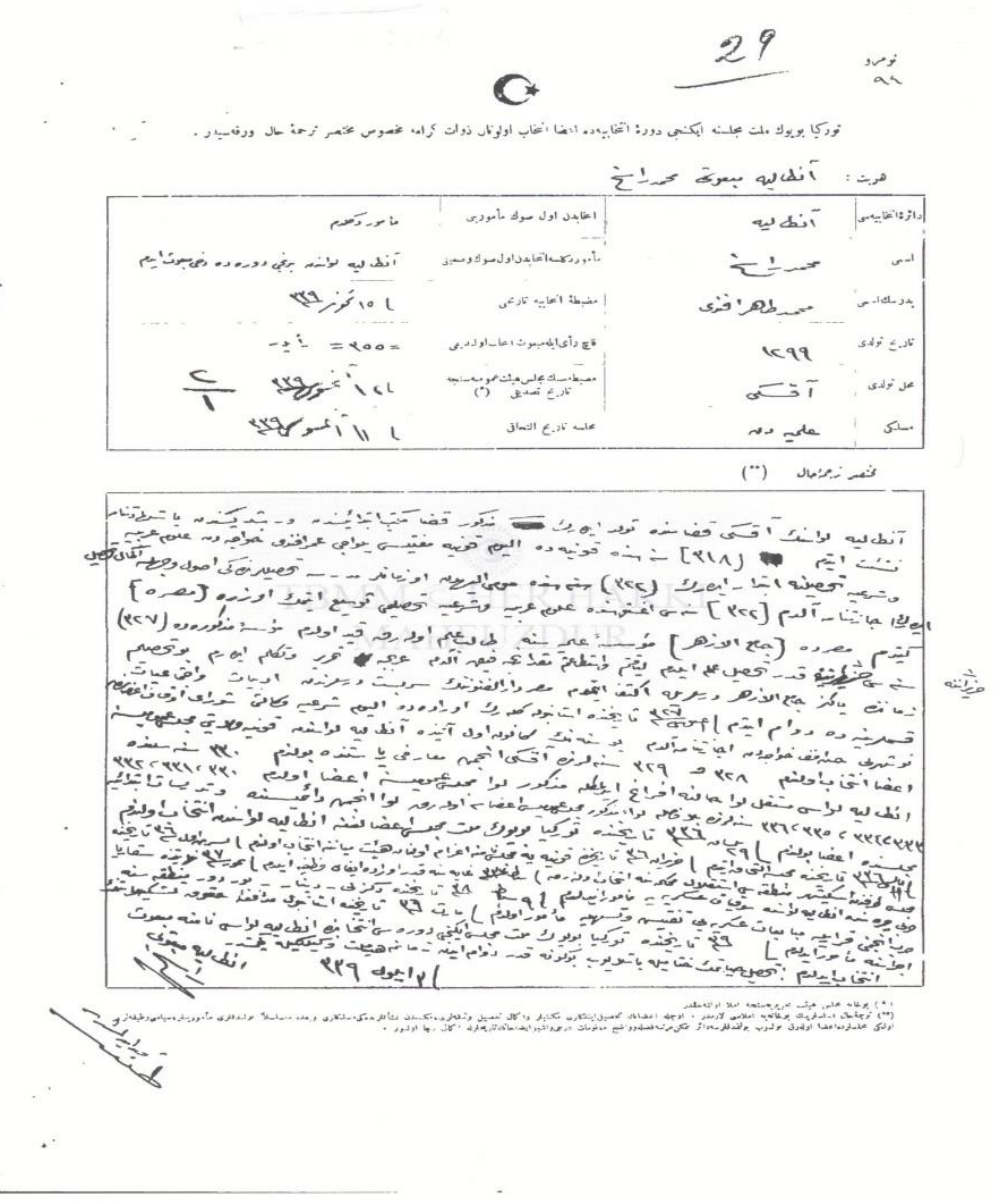

Ek 5: Rasih KAPLAN Tercüme-i Hal Kağıdı

\section{Kaynakça Bilgisi / Citation Information}

Sarıgüzel, N. (2017). Birinci Dönem Türkiye Büyük Millet Meclisinde Antalya Milletvekilleri (Biyografi Ve Faaliyetleri), OPUS - Uluslararası Toplum Araştırmaları Dergisi, 7(12), 205-236. 